\title{
Long-term radiographic and MRI follow-up of the distal interphalangeal joint after arthroscopic removal of large extensor process fragments
}

\author{
Natascha de Heer, Ellen Compagnie and Frerik ter Braake \\ Dierenkliniek Emmeloord, Emmeloord, The Netherlands
}

\begin{abstract}
Summary: Large extensor process fragments, occupying more than $25 \%$ of the joint surface of the distal interphalangeal joint, appear more often in Friesian horses. Arthroscopic removal of these large fragments has been described in a limited number of cases, but with a relatively good outcome. This study evaluates the long-term changes of the distal phalanx after arthroscopic removal of a large extensor process fragment using radiography and magnetic resonance imaging examination. Immediate post-operative and long-term follow-up (of more than five months) lateromedial radiographs after arthroscopic removal of large extensor process fragments of 11 operations on limbs in 10 horses were evaluated. The time between post-operative and follow-up measurements ranged from 5 to 45 months (mean $21 \pm 12$ months). All 11 cases showed subchondral new bone formation with relative elongation of the articular surface of the distal phalanx ranging from 28-92\% (mean $50 \pm 20 \%$ ) as a percentage relative to the articular surface of the navicular bone. Long-term follow-up magnetic resonance imaging examinations, available in four cases out of a total of three well-recovered horses, were performed between 13 and 45 months post surgery (mean $25 \pm 12$ months). Elongation of the articular surface of the distal phalanx by compact new bone formation in the subchondral region was visible in all four magnetic resonance imaging cases. In three cases, tissue compatible with spongious bone was present distal to the subchondral bone. This was lined distally by hypointense tissue, probably compact bone. Continuous to the articular cartilage, a layer of about the same thickness was present proximal to the subchondral new bone and the irregular tissue in the fragment bed with an intermediate signal on $\mathrm{T} 1$-weighted images. This study provides valuable information on the long-term adaptations of the distal phalanx following arthroscopic removal of large extensor process fragments.
\end{abstract}

Keywords: Extensor process fragments / low-field MR / horse / cartilage / follow-up / pseudo-cartilage

Citation: De Heer N., Compagnie E., Ter Braake F. (2015) Long-term radiographic and MRI follow-up of the distal interphalangeal joint after arthroscopic removal of large extensor process fragments. Pferdeheilkunde 31, 345-350

Correspondence: Dr. Natascha de Heer, Dierenkliniek Emmeloord, Espelerlaan 77, 8302 DC Emmeloord, The Netherlands, Email: ndheer@dierenkliniekemmeloord.nl

\section{Introduction}

Fragments of the extensor process of the distal phalanx are uncommon in horses and their cause remains speculative. They have multiple known aetiologies: trauma due to hyperextension, avulsion by the extensor tendon, a separate centre of ossification and osteochondrosis (Crowe et al. 2010, Dechant et al. 2000, Dyson 2011 , Fürst and Lischer 2012, Stashak 2002). Size of fragmentation can vary and large fragments, which can involve a sizable portion of the articular surface, seem to be present more often in young Friesian horses (Boerma et al. 2012).

Horses can be presented with a variable degree of lameness, but large fragments can also be an incidental finding during pre-purchase/survey radiographic examinations (Ter Braake 2005). Arthroscopic removal of these large extensor process fragments has been described in a limited number of cases, but with a relatively good outcome. Some form of remodelling of the distal phalanx was noticed in the long-term followup radiographic examination (Ter Braake 2005). However, radiography is a two-dimensional modality and has poor soft tissue contrast. Magnetic resonance imaging (MRI), on the other hand, has a very good soft tissue contrast and can provide detailed images in any anatomical plane. With the development of standing equine MRI, the anaesthetic risk of an $M R I$ examination under general anaesthesia is no longer an issue. Provided the foot remains static, movement due to the "sway" of the leg does not introduce significant motion-related image artifacts. The movement correction software available is deemed rarely necessary in foot cases. Low field MRI scanners have a lower signal compared with high-field scanners, resulting in a lower image resolution, but the advantages of scanning the horse without the need for general anaesthesia outweighs these limitations (Kinns and Mair 2005). Low-field MRI has also been reported to be able to detect cartilage alterations in the distal interphalangeal joint (DIJ, Olive 2010).

The purpose of this study is to further investigate and quantify the radiographic changes of the distal phalanx and DIJ reported previously and to evaluate the changes of the distal phalanx visible in the MRI examination.

\section{Material and Methods}

All horses included in this study had a large extensor process fragment removed arthroscopically at the Equine Department of the Veterinary Clinic Emmeloord. Large extensor process fragments were defined as fragments occupying more than $25 \%$ of the joint surface of the DIJ, consisting of the articular surface of the distal phalanx and navicular bone combined, as described by Ter Braake (2005). Follow-up lateromedial 
radiographs of the foot centred on the distal interphalangeal articulation had to be available immediately post-operative and long-term (of five months or more) for the subjects to be included in the study. In some of these cases, a long-term follow-up MRI examination in the standing, sedated horse using the equine MRI (Hallmarq Standing Equine MRI, Hallmarq
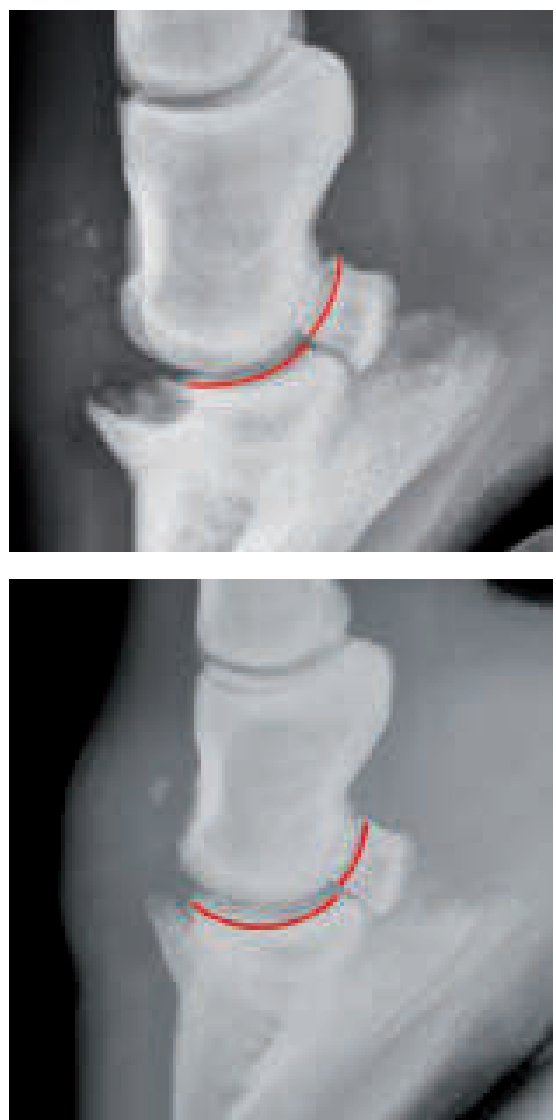

Fig. 1 Immediate post-operative (A) and long-term follow-up at 45 months post surgery (B) lateromedial radiographs centered on the distal interphalangeal articulation of the right front foot of a sevenyear-old Friesian horse (case 2). As an indicator of relative elongation of the articular surface of the distal phalanx, the total length of the articular surface of the distal phalanx was measured as a percentage of the articular surface of the navicular bone, in this case $+80 \%$.
Veterinary Imaging Ltd, Guildford, UK) with a 0.27 Tesla lowfield permanent magnet was performed. A standard imaging protocol was used, including three-dimensional (3D) T1weighted Gradient Echo (GRE) sagittal and frontal low- and high-resolution, two-dimensional T1-weighted GRE dorsal multiple-oblique low- and high-resolution, 3D T2*-weighted GRE sagittal images, 3D T2*-weighted GRE transverse images, and T2 Fast Spin Echo (FSE) sagittal and short tau inversion recovery (STIR) sagittal images. Additionally, 3D T1weighted GRE transverse, STIR and T2 FSE transverse were added if deemed necessary. All horses were sedated using a combination of $0.04 \mathrm{mg} / \mathrm{kg}$ BW romifidine IV (Sedivet ${ }^{\circledR}$, Boeringer Ingelheim B.V., Alkmaar, the Netherlands) and 0.1 $\mathrm{mg} / \mathrm{kg}$ BW morphine $\mathrm{HCl}$ IV (Morfine $\mathrm{HCl}^{\circledR} 10 \mathrm{mg} / \mathrm{ml}$, Pharmachemie B.V., Haarlem, the Netherlands).

An indicator of relative elongation of the articular surface of the distal phalanx was calculated from the lateromedial radiographs of the foot centred on the distal interphalangeal articulation by measuring the total length of the articular surface of the distal phalanx as a percentage of the articular surface of the navicular bone (Fig. 1). With this method, an attempt was made to control for the effect of image magnification and variation in patient size. The increase in subchondral new bone formation was measured by comparing the results of the immediately post-operative and long-term follow-up lateromedial radiographs of the foot. In some of the cases, the lateromedial post-operative radiographs clearly demonstrated an asymmetric shape of the fragment bed. The most palmar border of the fragment bed was used as a measuring point of the articular surface of the distal phalanx, in order to document the restored DIJ surface as well as possible.

\section{Results}

The study included 11 operations on limbs in 10 horses (case 9 and 11 is same horse, different leg) (Tab. 1). The condition was only found in fore-limbs. All cases showed one large fragment on the pre-operative radiographs. The relative size of the fragments, as a percentage of the total articular surface

\begin{tabular}{|c|c|c|c|c|c|c|c|c|}
\hline Case & $\begin{array}{l}\text { Age at } \\
\text { surgery }\end{array}$ & leg & $\begin{array}{c}\text { Size of fragment on } \\
\text { radiographs (\%) }\end{array}$ & $\begin{array}{l}\text { Follow-up } \\
\text { period (months) }\end{array}$ & $\begin{array}{l}\text { angle change of } \\
\text { extensor process }\left({ }^{\circ}\right)\end{array}$ & $\begin{array}{c}\text { relative elongation } \\
\text { articulation surface (\%) }\end{array}$ & MRI & Outcome \\
\hline 1 & $2 y$ & RF & 35 & 26 & 13 & +92 & & - \\
\hline 2 & $3 y$ & RF & 27 & 45 & 9 & +80 & $x$ & + \\
\hline 3 & $2 y$ & RF & 30 & 24 & 16 & +62 & & + \\
\hline 4 & $3 y$ & RF & 33 & 7 & 8 & +64 & & + \\
\hline 5 & $3 y$ & RF & 30 & 43 & 0 & +36 & & - \\
\hline 6 & $4 y$ & LF & 35 & 6 & 8 & +52 & & + \\
\hline 7 & $2 y$ & $\mathrm{LF}$ & 38 & 5 & 12 & +37 & & + \\
\hline 8 & $3 y$ & $\mathrm{LF}$ & 28 & 23 & 6 & +41 & & + \\
\hline 9 & $4 y$ & RF & 34 & 13 & 10 & +30 & $x$ & + \\
\hline 10 & $4 y$ & $\mathrm{LF}$ & 30 & 16 & 15 & +38 & $x$ & + \\
\hline 11 & $5 y$ & LF & 34 & 24 & 13 & +28 & $x$ & + \\
\hline
\end{tabular}


of the DIJ including the articular surface of the navicular bone, ranged from $27-38 \%$ (mean $32 \pm 3 \%$ ).

Radiographic evidence of pre-operative osteoarthritis was present in five cases and graded as minor changes. No evidence of osteoarthritis was present in six cases. The post-operative radiographs confirmed complete removal in 11 cases. Small opacities were present dorsal in the DIJ in the area of the common digital extensor tendon (CDET) on the post-operative radiographs in eight cases. The post-operative radiographs in three cases were without any remarks. Successful clinical outcome, characterized by the horses being sound in three gaits and performing according to the intended use, was present in 9 out of 11 cases (82\%). The time between post-operative and follow-up measurements was 5-45 months (mean $21 \pm 12$ months).

Evaluation of the immediate post-operative and long-term follow-up lateromedial radiographs showed subchondral new

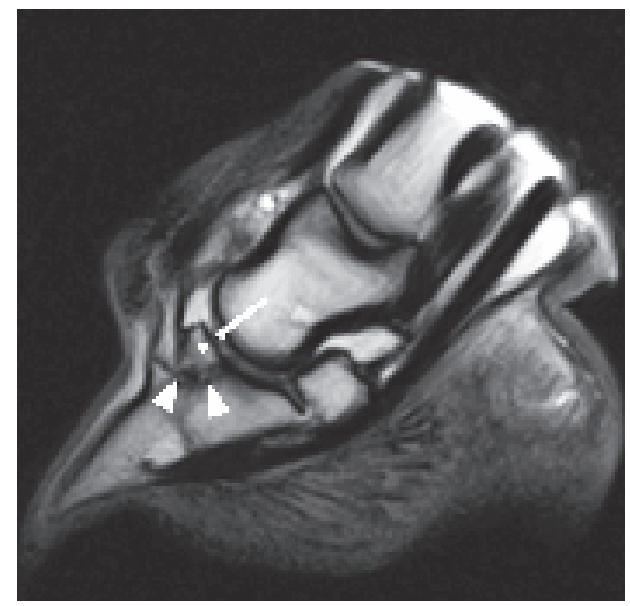

Fig. 2 Sagittal T2 FSE image of the left front foot of a six-year-old Friesian horse 24 months post surgery (case 11). The lining of the old fragment bed was visible as an irregular hypointense area in the medullary bone (arrow heads). Subchondral new bone formation was present in the fragment bed (arrow). Distal to it, the fragment bed was filled with tissue of moderate signal, compatible with the signal of spongious bone (asterisk), distally bordered by more irregularly shaped hypointense tissue.

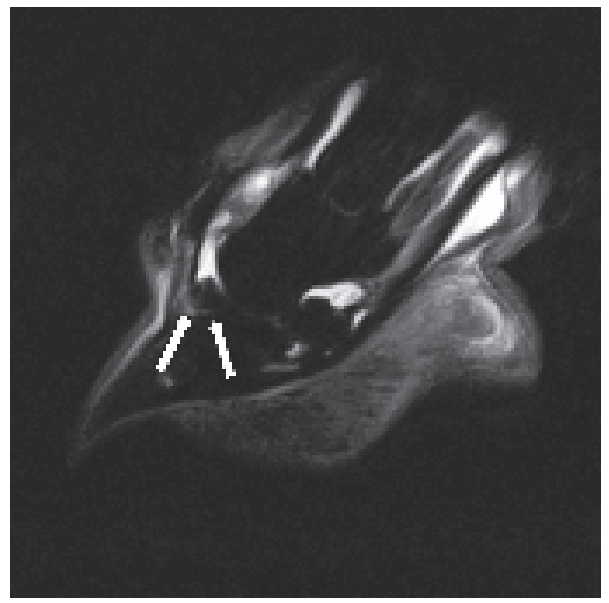

Fig. 3 Sagittal STIR image of the right front foot of a six-year-old Friesian horse 13 months post surgery (case 9). A linear area of moderate signal isointense with soft tissue signal is present dorsal to the lining of the old fragment bed (arrows). bone formation in all 11 cases. The relative elongation of the articular surface of the distal phalanx, as a percentage relative to the articular surface of the navicular bone, ranged from $28-92 \%$ (mean $50 \pm 20 \%$ ).

Additionally, a change in the direction of the bony proliferation at the attachment of the CDET was noted on lateromedial radiographs of the foot. The angle between the remodelled extensor process and the dorsal surface of the distal phalanx increased in time in all but one case (case 5) with an average of $10 \pm 4^{\circ}\left(\right.$ range $\left.0-16^{\circ}\right)$

Long-term follow-up MRI examination was present in four limbs of three horses. The follow-up MRI examination was performed between 13 and 45 months post surgery (mean $25 \pm 12$ months). All of the horses were clinically sound at the time of the MRI examination. In all MRI examinations, the lining of the old fragment bed was still visible as an irregular hypointense area in the medullary bone on the T1, T2* and T2 FSE images (Fig. 2). A linear area of moderate signal, compatible with soft tissue signal, was present dorsally to the lining of the old fragment bed on the STIR images in two cases (Fig. 3). Tissue of low signal was present in the subchondral area in the most palmar part of the fragment bed on all sequences (Fig. 2). Distal to it, in three cases, the fragment bed was filled with tissue of moderate signal, isointense to the signal of spongious bone on T1, T2* and T2 FSE images, distally bordered by more irregularly shaped hypointense tissue (Fig. 2). The distal part of the palmar defect in the fourth case was filled with more irregular hypointense tissue with small patchy areas of moderate signal tissue. Both this hypointense and moderate signal tissue was of low signal on the STIR images in all four cases. As this tissue was compatible with the new bone formation visible on the long-term follow-up radiographs made at the same time, the hypointense tissue was considered to be compact new bone formation in the subchondral region and the distal fragment bed. The tissue of more moderate signal was probably spongious new bone formation.

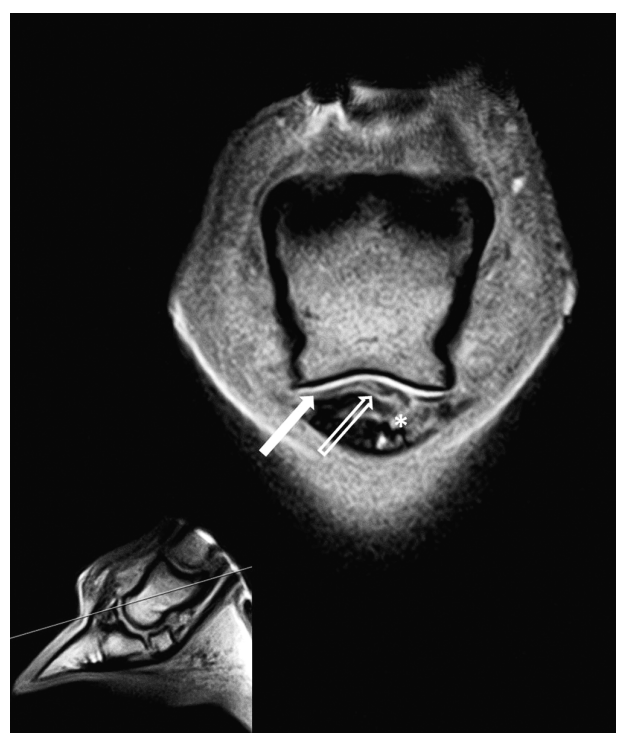

Fig. 4 Dorsal oblique TIGRE image of the foot of the right front foot of a seven-year-old Friesian horse (case 2). Medial is to the right. Dorsally in the distal phalanx, the defect was filled with patchy tissue of moderate signal (asterisk), with proximal, a layer of intermediate signal (arrow) with an undulating border (open arrow) mid-sagittal. 
The defect more dorsally in the distal phalanx was filled with patchy tissue of moderate signal on the T1, T2* and T2 FSE sequences (Fig. 4). This tissue was locally of moderate signal on STIR images isointense with the adjacent soft tissues in two cases.

Continuous to the articular cartilage, a layer of intermediate signal on the $\mathrm{T} 1$-weighted images was present proximal to the subchondral compact new bone and the irregular soft tissue in the fragment bed, thereby lining the complete fragment bed. This layer of tissue was subjectively of the same thickness as the articular cartilage. This layer had an undulating border mid-sagittal in the dorsal area of the DIJ in two cases (Fig. 4, 5). Multiple small areas of hypointense signal within this layer of tissue were visible on the $\mathrm{T} 1$ images on two orthogonal views in all cases (Fig. 6).

The DIJ was not distended in one case, mildly distended in two cases and moderately distended in the fourth case.

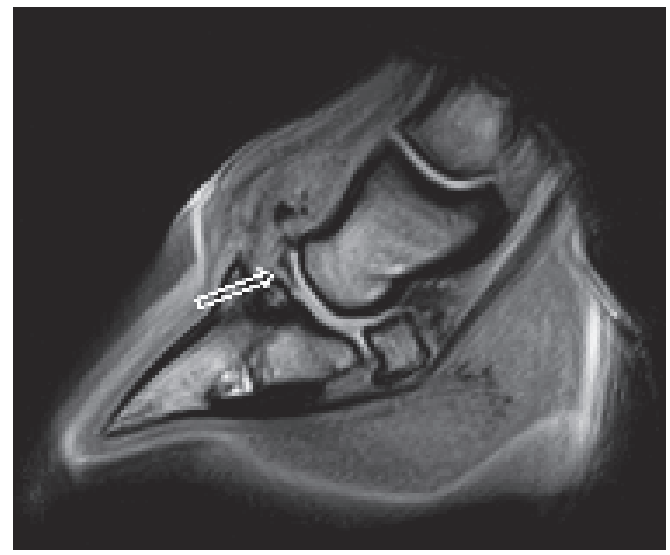

Fig. 5 Mid-sagittal T1 GRE image of the foot of the right front foot of a seven-year-old Friesian horse (case 2). The pseudo-cartilage layer of intermediate signal has an undulating border mid-sagittal in the dorsal area of the DIJ (open arrow).

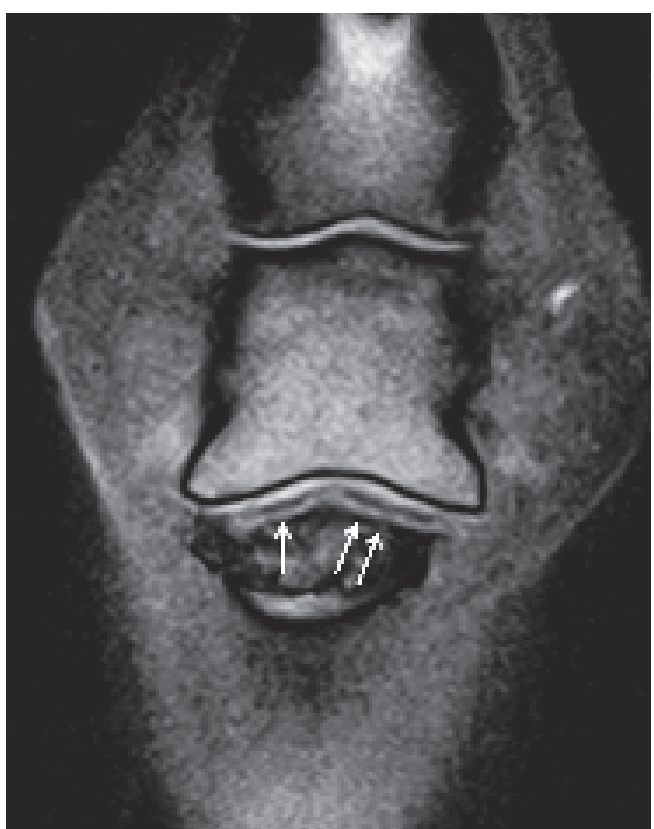

Fig. 6 Dorsal oblique T1 GRE image of the foot of a six-year-old Friesian horse 24 months post surgery (case 11). Multiple small areas of hypointense signal on T1 images were visible in the pseudocartilage (arrows).
Moderate intra-articular synovial proliferation was visible within the joint in all cases.

Small areas of hypointense signal in a triangular pattern in the soft tissues dorsal to the DIJ at the location of both portals were visible on the T1 and T2 FSE images in all cases, with compatible signal voids of a larger diameter on the T2* images.

\section{Discussion}

Remodelling of the subchondral bone at the fragment site was present in all 11 cases on the long-term follow-up radiographs. The relative elongation of the articular surface of the distal phalanx on the lateromedial radiographs was, on average, $50 \pm 20 \%(28-92 \%)$.

Additionally, a change in the direction of the bony proliferation at the attachment of the CDET was present on the lateromedial radiographs of the foot. The angle between the remodelled extensor process and the dorsal surface of the distal phalanx increased in time in all but one case (case five) with an average of $10 \pm 4^{\circ}$ (range $0-16^{\circ}$ ) (Compagnie et al., under review at Veterinary Surgery).

This remodelling is probably a reaction of the body to restore the normal anatomy of the distal phalanx and increase the weight-bearing articular surface. Unfortunately, dorso-palmar views of the foot were only available in a limited number of cases, therefore, changes in the orthogonal view could not be determined radiographically in the majority of cases.

Follow-up MRI examination was only available in four cases; pre-operative MRI examination was not performed in any of the cases. The old fragment bed could be detected on the sagittal MRI sequences as a hypointense irregular line in all the cases. This line corresponded to the fragment bed visible on the direct post-operative radiograph. A linear area of moderate signal was present dorsally on the STIR images in two cases. This signal change probably represents the presence of connective tissue near the lining of the old fragment bed, but signal changes because of mild bone-marrow oedema-type (BMO-t) lesions cannot be excluded (Powell 2011). Bone-marrow oedema-type lesions will show a low signal on the T1 sequences and on the T2* GRE images, and an artifactual signal void can occur in cases where the amount of water in the bone-marrow equals the amount of fat. This phenomenon is known as a chemical shift artifact of the second kind, or phase cancellation artifact, and results from equal amounts of signal from water and fat cancelling each other out. Such lesions can also present as a region of intermediate signal surrounded by a distinct low signal rim, where the phase cancellation is not complete in the area with intermediate signal because the amount of fluid exceeds the amount of fat. Extensive compact new bone formation and/or sclerosis was present in all four cases, causing low signals on the T1, T2*, T2 FSE and proton density images of the same area; $2^{*}$ images cannot be used to confirm mild BMO-t lesions (Murray and Werpy 2011, Olive et al. 2009, Werpy 2009). Bonemarrow oedema-type lesions are compatible with fibrosis, bone oedema, haemorrhage or bone necrosis (Dyson et al. 2005, Murray et al. 2006, Powell 2011 1). 
Elongation of the articular surface of the distal phalanx by compact new bone formation in the subchondral region was also visible in all four MRI cases. In three cases, tissue compatible with spongious bone was present distal to the subchondral bone. This was lined distally by hypointense tissue, probably compact bone. Additionally, more irregularly shaped compact bone was present in the more distal part of the palmar fragment bed in all four cases.

Continuous to the articular cartilage, a layer was present proximal to the subchondral new bone and the irregular tissue in the fragment bed. This layer was of intermediate signal on the $\mathrm{T} 1$-weighted images. This cannot be normal cartilage, but it was relatively about the same thickness as the remaining articular cartilage and present dorsal and adjacent to the subchondral new bone formation; therefore, we would like to refer to it as pseudo-cartilage. In two cases, this pseudo-cartilage had an undulating border mid-sagittal in the dorsal area, not completely fitting the opposite condyle of the middle phalanx. Multiple small areas of total discontinuity of the intermediate signal of the pseudo-cartilage were present in every case and were replaced by low signal intensity extending distal to the subchondral bone. This corresponds to full thickness lesions, as described by Olive (2010) in low-field $\mathrm{MRI}$, but as these lesions are not present in normal cartilage in our study, the comparison cannot be definitively made.

The pseudo-cartilage was best visualized on the standard and high-resolution 3D T1-weighted GRE sagittal and T1-weighted images in a dorsal multiple oblique plane with the slices oriented at right angles to the articular cartilage surface, as described to be most accurate for detecting articular cartilage lesions in the DIJ on low-field images (Olive 2010, Werpy et al. 2011 )

As all of the horses that underwent an MRI examination were sound and performing according to the owners' wishes, no pathologic examination of the changes found on the MRI was performed and the true nature of the tissues in the fragment defect could not be determined. The palmar part of the fragment bed is probably filled with compact bone, mimicking new subchondral bone, with spongious bone containing fatty tissue and more compact bone distal to it. We hypothesize that a combination of connective tissue and/or spongious bone with fatty tissue between the irregular compact bone is a probable explanation for the irregular tissue more dorsal in the fragment bed. We further hypothesize that the pseudocartilage is some form of fibrocartilaginous tissue. Considering the clinical presentation of these horses, the adaptive pseudo-cartilage is presumably clinically sufficient and the irregularities within the pseudo-cartilage are not real full thikkness lesions but can be structural differences within the composition of the pseudo-cartilage.

As an additional finding, small signal voids in a triangular pattern were present on the T2* images in the soft tissue dorsal to the DIJ at the location of both portals in all four cases, with small areas of hypointense signal on the corresponding T1 GRE and T2 FSE images, compatible with magnetic susceptibility artifact. Haemoglobin breakdown results in haemosiderin, and this causes a magnetic susceptibility image artifact, visible as a low signal area or even a signal void. T2* GRE sequences are most susceptible to this artifact, thus, comparing T2* GRE images to T2 FSE images can confirm the probable previous occurrence of haemorrhage (Boado et al. 2005, Murray and Werpy 2011). Air or dystrophic mineralization would also be differentials for low signal areas, but are less likely in these cases because no changes were detected at these sites on the radiographic examination on the same date.

The follow-up period of the horses that underwent an MRI examination ranged from 13 to even 45 months, and it has been reported that haemosiderin may remain within the tissues for months and years. A similar artifact may be created by very small metal shavings deposited following the arthroscopic procedure and cannot, therefore, be excluded (Murray and Werpy 2011).

In conclusion, all horses in this study showed a relative elongation of the articular surface of the distal phalanx on radiographic examination, and all but one showed an increase in the angle between the remodelled extensor process and the dorsal surface of the distal phalanx. On MRI examination, performed on four well-recovered cases, marked irregular new bone formation combined with irregular soft tissue was present in the fragment bed. A layer of adaptive pseudo-cartilage of very irregular structure was present dorsal to the fragment bed. These changes are probably a reaction of the body to restore normal anatomy of the distal phalanx and increase the weight-bearing articular surface. The follow-up MRI examinations provide valuable information on the longterm adjustments of the distal phalanx for clinical functionality and, therefore, could help the assessment of MRI examinations of horses with an unsuccessful outcome following arthroscopic removal of large extensor process fragments.

\section{References}

Boado A., Kristoffersen M., Dyson S., Murray R. (2005). Use of nuclear scintigraphy and magnetic resonance imaging to diagnose chronic penetrating wounds in the equine foot. Equine. Vet. Educ. 17, 62-68

Boerma S., Back W., Sloet van Oldruitenborgh-Oosterbaan M. M. (2012) The Friesian horse breed: A clinical challenge to the equine veterinarian? Equine Vet. Educ. 24, 66-71

Compagnie E., De Heer N., Ter Braake F., Back W. Arthroscopic removal of large extensor process fragments in 18 Friesian horses: long-term clinical outcome and radiological follow-up of the distal interphalangeal joint. submitted

Crowe O. M., Hepburn R. J., Kold S. E., Smith R. K. (2010) Long-term outcome after arthroscopic debridement of distal phalanx extensor process fragmentation in 13 horses. Vet. Surg. 39, 107-114

Dechant J. E., Trotter G. W., Stashak T. S., Hendrickson D. A. (2000) Removal of large fragments of the extensor process of the distal phalanx via arthrotomy in horse: 14 cases (1992-1998). J. Am. Vet. Med. Assoc. 217, 1351-1355

Dyson S. J., Murray R., Schramme M. C. (2005). Lameness associated with foot pain: result of magnetic resonance imaging in 199 horses (January 2001 - December 2003) and response to treatment. Equine Vet. J. 37, 113-121

Dyson S. J. (2011) Diagnosis and management of lameness in the horse. Saunders, Philadelphia, PA, 349-366

Fürst A. E., Lischer C. J. (2012) Foot. In: Auer J. A., Stick J. A. (eds): Equine Surgery. Saunders, St. Louis, Missouri, 1264-1299

Kinns J., Mair T. S. (2005) Use of magnetic resonance imaging to assess soft tissue damage in the foot following penetrating injury in 3 horses. Equine Vet. Educ. 17, 69-73 
Murray R. C., Blunden T. S., Schramme M. C., Dyson S. J. (2006) How does magnetic resonance imaging represent histologic findings in the equine digit? Vet. Radiol. Ultrasound 47, 17-31

Murray R., Werpy N. (2011). Equine MRI. Wiley-Blackwell, West Sussex, 101-145

Olive J., Mair T. S., Charles B. (2009) Use of standing low-field magnetic resonance imaging to diagnose middle phalanx bone marrow lesions in horses. Equine Vet. Educ. 21, 116-123.

Olive J. (2010) Distal interphalangeal articular cartilage assessment using low-field magnetic resonance imaging. Vet. Radiol. Ultrasound 51, 259-266.

Powell S. (201 1) Equine MRI. Wiley-Blackwell, West Sussex, 315-359

Ter Braake F. (2005) Arthroscopic removal of large fragments of the extensor process of the distal phalanx in 4 horses. Equine Vet. Educ. 17, 101-105

Stashak T. S. (2002) Adam's lameness in horses. Lippincott Williams and Wilkins, Baltimore, Philadelphia, 645-733

Werpy N. (2009) Diagnosis of middle phalanx bone marrow lesions in horses using magnetic resonance imaging and identification of phase effect canceling for proper image interpretation. Equine Vet. Educ. 21, 125-130

Werpy N. M., Ho C.P, Pease A. P., Kawcak C. E. (2011) The effect of sequence selection and field strength on detection of osteochondral defects in the metacarpophalangeal joint. Vet. Radiol. Ultrasound $52,154-160$

Erweiterte Zusammenfassung

\section{Röntgenologische und magnetresonanz- tomographische Langzeitkontrollen von Hufgelenken nach arthroskopischer Entfernung großer Fragmente des Processus extensorius}

Große Fragmente des Processus extensorius, welche mehr als $25 \%$ der Gelenkfläche des Hufgelenks (DIJ) ausmachen, treten bei Friesen oft auf. Die Pferde zeigen eine unterschiedlich ausgeprägte Lahmheit, doch können diese großen Fragmente auch bei Röntgenuntersuchungen im Rahmen einer Ankaufsuntersuchung einen Zufallsbefund darstellen. Diese Studie beurteilt die Langzeit-Veränderungen des Hufbeins nach arthroskopischer Entfernung eines großen Fragmentes des Processus extensorius mit Hilfe von Röntgen- und Magnetresonanztomographie-Aufnahmen. Alle Pferde dieser Untersuchung wiesen große Fragmente des Processus extensorius auf, die arthroskopisch entfernt wurden. Die Größe der Fragmente musste 25\% der Gelenkfläche des DIJ ausmachen und die gemeinsame Gelenksfläche von Huf- und Strahlbein erfassen. Von 11 operierten Gliedmaßen von 10 Pferden konnten lateromediale Zehenaufnahmen direkt postoperativ sowie bei der Langzeitkontrolle (nach mehr als 5 Monaten) nach arthroskopischer Entfernung der großen Fragmente des Processus extensorius beurteilt werden. Der Zeitraum zwischen postoperativen und späteren Kontrollen variierte zwischen 5 und 45 Monaten (durchschnittlich $21 \pm 12$ Monate). Auf den lateromedialen Aufnahmen der distalen Zehe zentriert auf das Hufgelenk wurde durch die Messung der totalen Länge der Gelenksfläche des Hufbeins als Prozentsatz der artikulären Fläche des Strahlbeines ein Indikator für die relative Verlängerung der Gelenkfläche des Hufbeins berechnet. Der am weitesten palmar gelegene Rand des Fragmentbetts wurde als Messpunkt für die artikuläre Fläche des Hufbeins genutzt, um so die Fläche des arthroskopierten DIJ so gut wie möglich zu dokumentieren. In allen 11 Fällen zeigte sich eine subchondrale Knochenneubildung mit einer relativen Verlängerung der artikulären Fläche des Hufbeins von

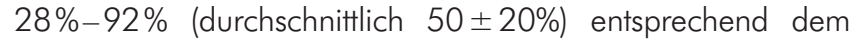
Prozentsatz relativ zu der Gelenkfläche des Strahlbeins. MRIKontrollaufnahmen nach 5 Monaten oder später standen von vier Gelenken von drei erfolgreich operierten Pferden zur Verfügung, diese wurden zwischen 13 und 45 Monate postoperativ (durchschnittlich 25 \pm 12 Monate) angefertigt.

In allen vier Fällen konnte eine Verlängerung der Gelenkfläche des Hufbeins durch Knochenneubildung der subchondralen Region festgestellt werden. In drei Fällen lag Gewebe entsprechend spongiösem Knochen distal des subchondralen Knochen vor. Dieses war distal durch hypointenses Gewebe, welches wahrscheinlich kortikalem Knochen entsprach, begrenzt. Bei dem vierten Fall war der distale Bereich des palmaren Defektes mit irregulärem Gewebe gefüllt, dieses enthielt kleine ungleichmäßige Bereiche mit Gewebe moderater Signalintensität. In allen vier Fällen wies das Gewebe mit hypointenser und moderater Signalintensität bei den STIR-Aufnahmen eine niedrige Signalintensität auf. Da dieses Gewebe mit der Knochenneubildung auf den gleichzeitig angefertigten Röntgenaufnahmen vergleichbar war, wird angenommen, dass das hypointense Gewebe der kortikalen Knochenneubildung in der subchondralen Region und dem distalen Fragmentbett entsprach. Das Gewebe mit moderatem Signal entsprach wahrscheinlich einer spongiösen Knochenneubildung. In Verlängerung des Gelenkknorpels lag eine Schicht gleicher Dicke mit einer intermediären Signalintensität auf den Tl gewichteten Aufnahmen proximal der subchondralen Knochenneubildung und dem irregulärem Gewebe im Fragmentbett vor. In zwei Fällen hatte diese Schicht mid-sagittal in der dorsalen Region des DIJ einen welligen Rand. Dies kann kein normaler Knorpel sein, allerdings wies die Schicht annährend dieselbe Dicke wie der verbleibende Knorpel. Auch befand sie sich dorsal sowie angrenzend an die subchondrale Knochenneubildung, weshalb anzunehmen ist, dass es sich um Pseudo-Knorpel handelt. In allen Fällen waren auf zwei orthogonalen T1-Aufnahmen innerhalb dieser Gewebeschicht viele kleine Bereiche hypointenser Signalintensität darstellbar. Dies entspricht den die gesamte Dicke betreffenden Läsionen, die von Olive (2010) im Niedrig-Feld-MRT beschrieben sind. Da in der vorliegenden Studie diese Läsionen nicht im normalen Knorpel vorlagen, kann jedoch kein definitiver Vergleich gezogen werden. Der palmare Bereich des Fragmentbettes ist wahrscheinlich mit Kompakta - entsprechend neu gebildeten subchondralen Knochen - einschließlich spongiösem Knochen mit Fettgewebe gefüllt und distal zu diesem lag weitere Kompakta vor. Wir nehmen an, dass eine Kombination von Bindegewebe und/oder spongiösem Knochen mit Fettgewebe zwischen der unregelmäßigen Kompakta eine mögliche Erklärung für das unregelmäßige Gewebe weiter dorsal im Fragmentbett ist. Des Weiteren vermuten wir, dass der Pseudo-Knorpel eine Form von Faserknorpel darstellt. In Hinblick auf die klinischen Befunde der Pferde, ist dieser adaptive Pseudo-Knorpel vermutlich klinisch gesehen adäquat und die Unregelmäßigkeiten innerhalb des Pseudoknorpels betreffen nicht die gesamte Dicke, können aber strukturelle Unterschiede innerhalb der Zusammensetzung des Pseudoknorpels sein. Das hier beschriebene Remodelling ist wahrscheinlich eine Reaktion des Körpers die normale Anatomie des Hufbeins wieder herzustellen und die gewichtstragende Gelenksfläche zu vergrößern.

Keywords: Processus extensorius / Fragment / MRT / horse / Knorpel / Verlauf / Pseudoknorpel / Orthopädie 